\title{
La memoria entre cenizas: un diálogo im- pertinente entre Tiempos del incendio de José Roberto Duque y Lo que va dictando el fuego de Juan Antonio Hernández.
}

\section{Memory in the Ashes: an Im-pertinent Dialogue between Tiempos del incendio by José Roberto Duque and Lo que va dictando el juego by Juan Antonio Hernández.}

\section{Resumen}

El trabajo propone una lectura de Tiempos del incendio (2014), de José Roberto Duque, y Lo que va dictando el fuego (2015), de Juan Antonio Hernández, como memoria y actualización de los sucesos del Caracazo (1989). Estos textos de Duque y Hernández pueden entenderse como «dispositivos colectivos de enunciación» (Deleuze, 1978) de una memoria popular -rebelde y militante- que no solo se opone a la versión oficial de los hechos, sino que reabre para el presente/futuro la interrogante sobre la utilización de la violencia de Estado como arma política durante el período de la democracia puntofijista (1958-1998). 


\section{Abstract}

This writing proposes a reading of Tiempos del incendio (2014), by José Roberto Duque, and Lo que va dictando el fuego (2015), by Juan Antonio Hernández, as a remembrance and update of the events that happened in El Caracazo (1989). This text by Duque and Hernández can be understood as «collective devices of enunciation» (Deleuze, 1978) from a popular memory - both rebel and militant - that doesn't only oppose to the official version of the events, but also starts again the questioning about the use of violence on behalf of the State as a political weapon during the puntofijista democracy (1958-1998) for the present/future.

Keywords memory, writing, political violence, democracy, Duque, Hernández.

\section{Memoria, escritura y poder: preliminares de un problema irresuelto}

Y sin embargo, no tenemos nada mejor que la memoria para garantizar que algo ocurrió antes de que nos formásemos el recuerdo de ello. (Paul Ricoeur. La memoria, la historia, el olvido)

Memoria y escritura responden, casi siempre, a un esfuerzo común. No hay escritura sin memoria, porque se escribe a partir de aquello que se recuerda, incluso cuando lo que se recuerda es fruto de la pura imaginación. La memoria constituye parte del engranaje mismo del relato, de su mecánica interna, sostiene — digamoslos hilos narrativos que le dan coherencia. Abrevar en las aguas del Leteo equivaldría para la escritura a la pérdida de toda razón y quebraría su estructura hasta el punto de hacérnosla ininteligible. Acaso ahí reside la razón de que, para los griegos, Mnemosine fuera una de las musas de la escritura, de la poesía y del arte en general.

La inversión de esa relación entre memoria y escritura puede, sin embargo, no ser tan acertada. Si no es posible escribir sin hacer al menos un mínimo ejercicio 
de memoria, recordar no implica necesariamente el hecho escritural, el relato de lo recordado. Quizá por eso, valdría la pena establecer cierta distinción entre memoria y recuerdo: «el simple recuerdo — afirma Ricoeur en La memoria, la historia, el olvido - sobreviene a la manera de una afección, mientras que la rememoración consiste en una búsqueda activa» (36) de lo que quiere ser recordado. Ricoeur se refiere aquí a la distinción que hacía Aristóteles entre mnēme y anamnēsis como un anticipo de la diferenciación que establece hoy la fenomenología de la memoria entre la «evocación simple» y la «búsqueda o esfuerzo de recordación»:

Entendemos por evocación el advenimiento actual de un recuerdo. A ella reservaba Aristóteles el término de mnēme, mientras que con el de anamnēsis designaba lo que nosotros llamamos más tarde búsqueda o rememoración. Caracterizaba la mnème como pathos, como afección: puede suceder que nos acordemos, de esto o de aquello, en tal o cual ocasión; percibimos entonces un recuerdo. Por lo tanto, la evocación es una afección por oposición a la búsqueda. (Ricoeur 46)

La memoria, si bien mantiene un vínculo de origen con esa afección que es el recuerdo, implica un esfuerzo, la búsqueda consciente de datos y antecedentes, la implementación de distintas metodologías investigativas - e imaginativas - que actúan directa o indirectamente sobre las huellas materiales, físicas, psíquicas y documentales del pasado. Ese esfuerzo, la fuerza que voluntariamente ejerce un determinado sujeto sobre las huellas del pasado, es lo que lleva a Elizabeth Jelin a definir la memoria como trabajo. Para Jelin, el trabajo es «un signo distintivo de la condición humana» que «pone a la persona y a la sociedad en un lugar activo y productivo» (14). Desde esa perspectiva, es importante subrayar esa visión «activa» $\mathrm{y}$ «productiva» de la memoria que se opone por completo y cabalmente a la noción del pasado como cosa dada, como objeto perdido y, por tanto, recuperable. En cuanto al trabajo de la memoria se refiere, su objetivo no implica en modo alguno 
un proceso de recuperación sino, en cualquier caso, de representación, lo que nos conduce sin duda de nuevo a la escritura.

En esa dirección, Beatriz Sarlo explica que «llamamos experiencia a lo que puede ser puesto en relato, algo vivido que no solo se padece, sino que se transmite» (31). Si el recuerdo parece reducirse a una afección involuntaria circunscripta al ámbito de lo subjetivo, el esfuerzo que implica la memoria pasa casi siempre del ámbito puramente privado a la esfera de lo público y ese salto es posible gracias a la representación, al lenguaje, al discurso. «No hay testimonio sin experiencia explica Sarlo-, pero tampoco hay experiencia sin narración: el lenguaje libera lo mudo de la experiencia, la redime de su inmediatez o de su olvido y la convierte en lo comunicable, es decir, lo común» (Sarlo 29). Eso comunicable de la experiencia pretérita «corona» los procesos de recordación y es entendido por Ricoeur como «conocimiento». Para el filósofo francés, podemos determinar dos enfoques superpuestos en los procesos de recordación, el cognitivo y el pragmático: «el conocimiento, que corona la búsqueda conseguida, designa la cara cognitiva de la rememoración, mientras que el esfuerzo y el trabajo se inscriben en el campo práctico» (Ricoeur 81). Sarlo hace incapié también en el entendimiento al que debería conducir el ejercicio mnemónico y señala que «[e]s más importante entender que recordar, aunque para entender sea preciso, también, recordar» (26). El trabajo intelectual al que alude el ejercicio de hacer memoria, implica entonces no solo la producción sino también la transmisión de saber.

Eso a lo que llamamos memoria, se inscribe así en otro lugar que el del «simple recuerdo». Hablamos de una construcción simbólico-discursiva que actúa en distintos órdenes sociales, culturales, políticos e incluso jurídicos, e incide tanto a nivel individual y privado, como a nivel colectivo y público. Al entender la memoria como conocimiento, estamos señalando que esta opera según las prerrogativas, los parámetros y los intereses que determinan qué forma y qué no forma parte del saber, qué puede ser entendido y aceptado como «conocimiento» $y$ qué no. El conocimiento acerca del pasado, enunciado como historiografía o como memoria, como autobiografía o como testimonio, implicaría entonces «oscuras 
relaciones de poder» (Foucault 21). El conocimiento no está ahí afuera, ni puede salir a buscárselo como un objeto a descubrir, se lo construye desde el quehacer humano y su enunciación es, en muchos casos, un elemento central de ese proceso productivo.

Para saber qué es, para conocerlo realmente, para aprehenderlo en su raíz, en su fabricación, debemos aproximarnos a él no como filósofos sino como políticos, debemos comprender cuáles son las relaciones de lucha y de poder. Solamente en esas relaciones de lucha y poder, en la manera como las cosas entre sí se oponen, en la manera como se odian entre sí los hombres, luchan, procuran dominarse unos a otros, quieren ejercer relaciones de poder unos sobre otros, comprendemos en qué consiste el conocimiento. (Foucault 28)

El pasado no es, entonces, un territorio neutral, un archivo cerrado del que se obtienen datos e informaciones más o menos veraces o verificables sobre los acontecimientos pretéritos, sino sobre todo una construcción discursiva, política e ideológicamente implicada en la lucha presente por el poder. Por ello, como señala Jelin, «es imposible encontrar una memoria, una visión y una interpretación únicas del pasado, compartidas por toda una sociedad»(2). Al contrario, debemos «reconocer a las memorias como objetos de disputas, conflictos y luchas, lo cual apunta a prestar atención al rol activo y productor de sentido de los participantes en esas luchas, enmarcados en relaciones de poder» (Jelin 2). Precisamente, la memoria fluctúa, deriva, se transforma, en el presente, gracias a las acciones, a los trabajos, a los esfuerzos, de los sujetos que operan sobre ese pasado en cuestión. En ese sentido, entendemos que el trabajo de la memoria, al verse comprometido en las pugnas del presente por el poder, no implica solo un esfuerzo contra el olvido, natural o impuesto, sino también y principalmente contra otras memorias.

\section{Memorias de la violencia: el pasado en cuestión}


"La vida ha sucumbido ante la muerte, pero la memoria sale victoriosa en su combate contra la nada" (Tzvetan Todorov. Los abusos de la memoria)

No todo pasado se presenta como objeto de conflicto, claro está. Algunos episodios reclaman para sí más y mejor atención, tanto por su significación histórica como por las implicaciones que puedan seguir teniendo en el presente. Esa relevancia coincide casi siempre con eventos de naturaleza trágica o violenta, con conflictos armados, períodos de represión, autoritarismos o dictaduras que dejan heridas en la psiquis individual y colectiva:

la memoria y el olvido, la conmemoración y el recuerdo se tornan cruciales cuando se vinculan a acontecimientos traumáticos de carácter político y a situaciones de represión y aniquilación, o cuando se trata de profundas catástrofes sociales y situaciones de sufrimiento colectivos. (Jelin 10-11)

La violencia política reclama la necesidad de recordar precisamente porque, como veíamos con Sarlo, urge la necesidad de entender, de comprender lo ocurrido, pero también, como vimos, de transmitirlo. Ricoeur apunta también en esta dirección cuando señala que «las pruebas, las enfermedades, las heridas, los traumatismos del pasado invitan a la memoria corporal a fijarse en incidentes precisos que apelan fundamentalmente a la memoria secundaria, a la rememoración, e invitan a hacer su relato» (62).

Pero no se trata solo de comprender y transmitir la experiencia pasada. Casi siempre, los procesos de recordación, de anamnēsis, de representación y actualización del pasado, están vinculados a la implementación de justicia. Los vínculos y las implicaciones que el pasado mantiene todavía en el presente determinan el grado de conflictividad que su rememoración pueda acarrear. El conflicto se acentúa cuando «el pasado recordado es demasiado cercano y, por eso, todavía juega funciones políticas fuertes en el presente [sobre todo, cuando] quienes 
recuerdan no están retirados de la lucha política contemporánea; por el contrario, tienen fuertes y legítimas razones para participar en ella y para invertir en el presente sus opiniones sobre lo sucedido» (Sarlo 82-83). Las razones para revisar los episodios de violencia social y política pugnan no solo contra el olvido, natural o impuesto, sino también y sobre todo contra la impunidad. En estos casos, los procesos de recordación y de memoria no se presentan solo como un derecho, sino que conllevan implicaciones políticas, jurídicas e incluso éticas. Como señala Todorov, «[c]uando los acontecimientos vividos por el individuo o por el grupo son de naturaleza excepcional o trágica, tal derecho se convierte en un deber: el de acordarse, el de testimoniar» (26).

\section{El Caracazo: la violencia como signo político en Venezuela}

Si un episodio marcó la memoria colectiva venezolana a finales del siglo XX, fueron los sucesos del Caracazo. La explosión social de febrero de 1989 sacudió los cimientos políticos y sociales y las heridas de la cruenta represión de la que fueron objeto las protestas, persisten en el presente y llaman a la reflexión sobre ello, no solo porque no se ha superado el trauma causado por la violencia institucional militar-policial o porque muchos de los crímenes de lesa humanidad cometidos por el Estado venezolano en ese momento, siguen impunes, sino también porque las razones que condujeron a la protesta masiva continúan vigentes, incluso en muchos sentidos se han recrudecido, y el estallido es una amenaza que se cierne todavía sobre nuestra compleja realidad político-social.

El 27 de febrero de 1989, la policía metropolitana asesinó a Yulimar Reyes, estudiante de la escuela de Letras de la Universidad Central de Venezuela. Minutos antes, Reyes había dado unas declaraciones ante los medios de comunicación explicando las razones de las fuertes protestas que se habían extendido de Guarenas a Caracas y amenazaban ya con extenderse a las principales ciudades del país. Reyes sería la primera de cientos, acaso miles de víctimas, que la represión por 
parte del gobierno de Carlos Andrés Pérez regaría a lo largo y ancho del territorio nacional tras ordenar la militarización de la vida pública nacional y suspender garantías constitucionales fundamentales. Pero, ¿qué causó la revuelta popular y qué llevó al gobierno de Pérez a usar a la fuerza armada nacional para retomar el control?

Un par de meses antes, el 4 de diciembre de 1988, Carlos Andrés Pérez había resultado electo por segunda vez Presidente de la República, para el período 1989-1994. Pérez había fundado su campaña electoral en la promesa demagógica de sacar al país de la profunda crisis económica, social y política que treinta años de rentismo petrolero, corrupción y clientelismo habían recrudecido, amparado en el espejismo de bienestar de primer gobierno (1974-1979). El ilusorio bienestar de entonces, publicitado bajo el lema de «la Gran Venezuela», escondía en verdad una serie de medidas de corte populista sostenida artificialmente gracias al alto precio de los hidrocarburos, que no atacaron nunca los problemas estructurales de nuestro modelo económico periférico, condenado a ser proveedor seguro de materias primas de los centros de poder, principalmente en materia de hidrocarburos.

El 5 de febrero de 1989, en un alarde de que los buenos tiempos habían vuelto, Pérez toma posesión del cargo en un acto rimbombante y ostentoso que la imaginación popular catalogó como “La coronación”. La promesa del retorno de la riqueza duró poco. Menos de 15 días después, el 16 de febrero de ese mismo año, Pérez anuncia al país un plan de reajustes económicos que amenazaba con sumir a la población todavía más en la miseria. El denominado «paquetazo» consistía en un nuevo endeudamiento con el Fondo Monetario Internacional y la subordinación de la economía venezolana a un plan de ajustes dictado por este organismo que incluía la liberación de los precios y de las tasas de interés, el aumento de los servicios públicos, la privatización de empresas estatales estratégicas, entre otras medidas, que impactaron de forma directa en la ya pauperizada situación económica del venezolano. Los desequilibrios macroeconómicos, las políticas populistas y clientelares, la corrupción y el casi nulo aparato productivo interno, habían descalabrado las finanzas del país petrolero. El plan anunciado por Pérez no solo 
no preveía una intervención estatal que minimizara el impacto del plan de ajustes sobre los sectores más desfavorecidos de la población, sino que llamaba a estos a soportar las consecuencias económicas directas y sacrificarse en nombre de una democracia que poco y nada les había aportado.

La protesta se inició el 27 de febrero, durante las primeras horas del día, en las ciudades de Guarenas y Guatire, extendiéndose rápidamente a Caracas. Lo que se inició como una protesta en contra del aumento del transporte público, consecuencia inmediata del aumento de la gasolina, derivó en una masiva expresión del descontento popular. Miles de personas atestaron el espacio público paralizando toda actividad cotidiana. Horas después, «se inició un festivo saqueo de los comercios, de bodeguitas a supermercados, que todo el mundo visualizó como una fiesta» (Izard 104). Harta de estar harta, la gente decidió tomar por la fuerza lo que por mucho tiempo les había sido negado: comida, ropa, electrodomésticos, la capacidad misma de comprar todo aquello que el sistema les ofrecía y les negaba a un tiempo. Pronto, las protestas no solo sobrepasaron la capacidad de respuesta de la policía sino que, en muchos casos, esta se sumó a los manifestantes para “organizar" los saqueos, beneficiándose también de estos. Los funcionarios policiales sostenían por entonces una batalla particular por sus propias reivindicaciones salariales y la falta de respuesta de las autoridades facilitó que los primeros se inclinaran a favor de los manifestantes.

Pérez decidió ser permisivo al principio, pero tras dos días de protestas y viendo que las manifestaciones cobraban visos de rebelión, decidió activar a las Fuerzas Armadas Nacionales (FAN) para recuperar el control y retornar al orden. Las consecuencias no se harían esperar. La gran fiesta del populacho no podría terminar más que en un baño de sangre. El desafío de los sectores populares al poder, un poder acostumbrado además a usar la fuerza y la violencia como "defensa legítima" de la democracia, no solo no pasaría desapercibido, sino que, desde la lógica de ese poder, debía recibir la más dura reprimenda. Tras la orden de Pérez de activar el Plan Ávila, Las FAN actuaron durante esos días como un verdadero ejército de ocupación, disparando a mansalva contra cualquiera que participara en 
las protestas o que simplemente incumpliera con el toque de queda decretado a partir de las 6.00 p.m.

Más allá de los hechos en sí mismos, el evento cobra un interés político y sociológico sin precedentes para analizar el panorama político venezolano del último entre siglo. En esa dirección, y rescatando la pertinencia y el carácter político del Caracazo, Reinaldo Iturriza identifica el exceso que caracterizó la revuelta con la conformación de una «turba», un movimiento «tan feroz como feliz» que contribuye a la liberación de las tensiones, pero cuya presencia y desarrollo amenaza la existencia misma de la autoridad. La turba — explica Iturriza a partir de Deleuze y Guattari - no persigue un nuevo orden; por el contrario, arremete violentamente contra todo signo de autoridad y pretende, si no evitar, al menos distanciar la vuelta de un orden al que sabe injusto. Precisamente, la turba aparece ahí donde toda representatividad ha colapsado, donde el poder ha dejado de ser representativo y la violencia de Estado ha opacado ya toda política. La turba eclipsa la existencia misma del poder y su aparición puede ser entendida como un momento de liberación que suspende toda opresión. Lo perturbadora de su existencia se debe precisamente al hecho de que no persigue un nuevo orden, ni un Estado nuevo, sino el desorden de la ausencia misma de poder, la desestructuración social mediante la exposición de que las diferencias sociales y económicas se han hecho insalvables. Si superficialmente observamos a la gente derribando las vidrieras, asaltando el comercio, quemando los establecimientos, símbolos y estructura del mercado; lo que está de fondo es un profundo rechazo al desequilibrio en la organización del poder y de la sociedad. En ese sentido, afirma Iturriza, «lo realmente peligroso no es que la turba acometa el saqueo. Lo peligroso es la existencia misma de la turba» (75). La tesis de Iturriza desmonta los análisis conservadores que restaron o intentaron restar el carácter profundamente político y liberador del Caracazo. El divorcio de la turba con toda forma de poder, constituye la verdadera amenaza y es contra ella contra la que se toma la decisión de suprimirla por la fuerza. Desde ese momento, el choque es inevitable, la matanza también. 
Según las fuentes que se consulten, durante esos días hubo en el país entre trescientos y dos mil asesinatos a manos de los efectivos castrenses. Los efectivos militares, no contentos con reprimir, perseguir y asesinar a las personas en las calles, dispararon durante noches enteras contra los edificios de apartamentos de clase popular con armas de guerra. Las imágenes de las viviendas prácticamente destruidas por la artillería revela que, más allá de recuperar el control político, se buscaba «aterrorizar de tal manera a los vencidos que más nunca les quedaran ganas de intentarlo otra vez» (Iturriza 83). La determinación de sembrar el terror en el seno mismo del movimiento popular revela que la represión cobró durante esos días visos claros de terrorismo de Estado. Lo que se perseguía era

lograr que los vencidos no tuvieran la experiencia de haber ganado una. Que esa semana se les clavara a fuego; no como el día en que se adueñaron de la calle y compraron sin pagar, sino como las noches terribles e interminables en que llovían sin tregua las balas y se vivió agazapado en completa indefensión. (Iturriza 84)

El escarmiento intentaba aplastar el espíritu insumiso que el pueblo mostró durante la revuelta, su fuerza desgarradora, su capacidad para rebelarse contra un poder que consideraba ya entonces ilegítimo. Por eso la represión fue «una acción punitiva contra los enemigos [y] no un acto de disuasión dirigido a conciudadanos», como se afirmó pocos días después en una editorial de la revista SIC, que recoge también Iturriza (84). El terrorismo de Estado, antes que imponer orden, busca someter a la población, sometiéndolo por la fuerza e inculcándole una actitud de obediencia y de colaboración, pero también escarmentándola, para que no reincida en su actitud desafiante.

\section{El asesinato de Gonzalo Jaurena}


El Caracazo no supuso el fin de la violencia. Aunque hubiera cabido esperar que el exceso de violencia que copó el espacio público esos días pudiera haber conducido a una reflexión por parte de las instancias de poder para minimizar el uso de la fuerza ante el descontento popular, la verdad fue que ocurrió todo lo contrario. El Estado venezolano se empeñó de tal modo en justificar los excesos de la represión ocurrida entre febrero y marzo de 1989, alegando que se había hecho uso de una fuerza legítima en defensa de la democracia y que se había desarticulado una conspiración, que incluso llegó a condecorar en un acto público a los efectivos militares que habían perpetrado la masacre:

[1]a opinión del gobierno sobre lo ocurrido estuvo tan ligada a la idea de que se había derrotado a la subversión que incluso se llegó a hacer un reconocimiento a los soldados que habían masacrado al pueblo a través del general de división del Ejército José María Troconis Peraza, quien en un acto les felicitó: "El país se construye con este quehacer diario. Con el sacrificio de cada uno de sus hijos. Ustedes han dado el ejemplo de cómo se edifica una nación, de cómo se va hacia adelante. Por eso los felicito, y les expreso mi mayor gratitud en nombre de la República y en el mío propio". (Rada y Contreras 120-121)

Las declaraciones de Troconis no podrían haber sido más precisas. El modelo democrático instaurado en Venezuela tras el derrocamiento de la dictadura militar de Marcos Pérez Jiménez se había fundamentado y se sostenía en el uso estatal de la violencia, mediante la implementación de políticas y prácticas altamente represivas. El uso de la fuerza contra los adversarios políticos eran una marca distintiva del ejercicio del poder en Venezuela, desde los levantamientos militares de Barcelona (26/06/1961), Carúpano (04/05/1962) y Puerto Cabello (02/06/1962), pasando por la larga y cruel política antisubversiva durante las décadas de la lucha guerrillera $(60,70$ y 80), hasta las masacres de Cantaura (04/10/1982), Yumare (08/05/1986), El Amparo (29/10/1988) y el mismo 
Caracazo. La violencia parecía no solo estructural, sino consustancial a ese modelo democrático. Entre 1958 y 1998, la instrumentalización de la violencia definirá la política de seguridad y defensa de Venezuela, justificada en la lucha contra la amenaza del comunismo y el enemigo interno (Battaglini, La posguerra).

La instrumentalización de la violencia condujo al Estado venezolano a proseguir la política represiva tras las protestas. La suspensión de las garantías constitucionales, la persecución, captura y retención de distintos líderes políticos y estudiantiles que sucedieron al Caracazo extendieron el clima de terror e indefensión de esos días:

[L]a decisión del gobierno de suspender las garantías constitucionales fue aliciente para desarrollar una política de persecución a todas aquellas personas consideradas como parte de una oposición subversiva, capaz de originar desórdenes y protestas o de haber tenido una actuación significativa en los días de la protesta generalizada. (Rada y Contreras 121)

El movimiento estudiantil fue, sin dudas por el carácter crítico y contestatario que recobró durante esos días, uno de los objetivos principales de esa política de persecución y amedrentamiento. Estudiantes universitarios y de secundaria fueron víctimas de la más brutal represión, muchos jóvenes fueron encarcelados $\mathrm{y}$ torturados, otros resultaron heridos y algunos, demasiados podríamos decir, perdieron la vida a manos de los organismos de seguridad del Estado. Rada y Contreras señalan incluso eventos claramente extremos, violatorios de los derechos humanos fundamentales y de los convenios internacionales suscritos la nación: «la represión de los cuerpos militares y policiales en contra de las manifestaciones estudiantiles llegó a los extremos de allanar LUZ ${ }^{1}$ y usar armas

\footnotetext{
${ }^{1}$ La Universidad del Zulia
} 
CATEDRAL TOMADA: Revista de crítica literaria latinoamericana / Journal of Latin American Literary Criticism La memoria entre cenizas: un diálogo im-pertinente entre Tiempos del incendio de José Roberto Duque y Lo que va dictando el fuego de Juan Antonio Hernández.

químicas prohibidas por la Organización de Naciones Unidas contra los estudiantes» (Rada y Contreras 126-127).

En esas circunstancias, las organizaciones políticas — tanto estudiantiles como comunitarias - debatían la pertinencia de confrontar o no al Estado. Mientras unos argumentaban la necesidad de aprovechar el clima insurreccional para propiciar una "confrontación definitiva", otros apostaban por una retirada táctica que permitiera evaluar los acontecimientos, a la espera de la recomposición de las fuerzas sociales y políticas en pugna. El joven estudiante de Ingeniería Electrónica de la Universidad "Simón Bolívar", Gonzalo Jaurena, era uno de los que defendían la primera tesis y se unió a las protestas estudiantiles que se llevaban a cabo en algunos sectores de Caracas, protagonizadas en su mayoría por estudiantes de educación media. El 4 de abril de 1989, Jaurena fue detenido en una de esas protestas por efectivos de la Policía Metropolitana, golpeado, torturado y finalmente asesinado dentro de una "perrera" ${ }^{2}$. Jaurena es considerado por muchos la última víctima del Caracazo y se ha convertido en una referencia obligada de esos días ${ }^{3}$, pero también en un símbolo de la rebelión popular en Venezuela.

Con el asesinato de Jaurena como centro neurálgico del relato, Tiempos del incendio y Lo que va dictando el fuego reivindican la memoria del otro, de la víctima, de sus herederos; una memoria clandestina, subalterna y contra-oficial que desdice la Verdad del poder desde una enunciación colectiva y popular ${ }^{4}$. Su lectura

${ }^{2}$ Mote con el que se designa a ciertos vehículos de la policía en Venezuela.

${ }^{3}$ Igual peso histórico y simbólico tiene el asesinato de Yulimar Reyes, la primera víctima del Caracazo. Reyes, estudiante de Letras de la Universidad Central de Venezuela, fue asesinada por efectivos de la Policía Metropolitana justo después de haber ofrecido declaraciones a un canal de televisión sobre el carácter político de las manifestaciones que se estaban produciendo en Caracas en contra del paquete de medidas económicas anunciado por el recién electo presidente Carlos Andrés Pérez.

${ }^{4}$ No cabe duda de que los textos de Duque y Hernández filian con la tradición de lo que en América Latina se ha denominado "nueva novela histórica", largamente debatida entre los años 70 y 80 (Cf. Pons, Cristina. Memorias del Olvido). Sin embargo, hemos querido evadir ese debate y afirmarnos en una diferenciación que nos parece pertinente, la diferencia que separa (y une) historia y memoria. Maurice Halbawchs apunta en La memoria colectiva que podemos distinguir entre la «memoria autobiográfica» («interior o interna») y la «memoria histórica» («exterior»). Luego, aclara: «No es sobre la historia aprendida sino sobre la historia vivida que se apoya nuestra memoria» (106). En ese sentido, hemos querido proponer estos textos antes como 'escrituras de 
nos recuerda que, a pesar de la sangre, a pesar del dolor y la tristeza por los caídos, el Caracazo cobra también visos épicos, acaso por la fuerza misma de la insurrección. Es, podríamos decir con Slavoj Žižek, un "acontecimiento", en los términos en los que lo plantea Alain Badieu. Es decir, un evento social de tal magnitud y relevancia, que suspende por un instante toda la compleja red de relaciones de poder y permite, al mismo tiempo, vislumbrar la Utopía. Desde esa perspectiva, Duque y de Hernández —entre otras que forman parte de una investigación más amplia - plantean una memoria revolucionaria de la rebelión popular del Caracazo, que otros discursos habían suspendido.

\title{
5. Memorias del fuego: metáforas del tiempo y de la guerra
}

\begin{abstract}
"La vida ha sucumbido ante la muerte, pero la memoria sale victoriosa en su combate contra la nada". (Tzvetan Todorov. Los abusos de la memoria)
\end{abstract}

La metáfora del fuego para referirse al tiempo no es extraña ni ajena, sino cotidiana. Después de todo, asociamos el paso de los días a la alborada y al ocaso del Sol. Como el fuego, el tiempo todo lo devora. La irrecuperabilidad del pasado sostiene esa metáfora, pues ambos no dejan a su paso sino cenizas. Recordemos la interpretación que hacía Walter Benjamin del Angelus Novus, el dibujo de Paul Klee que le inspiró en su postulación de las Tesis sobre la filosofía de la Historia. Desde ahí, intuimos la escritura de la memoria como oposición y resistencia al tiempo, a su transcurrir incendiario. Las escrituras de la memoria miran atrás como

\footnotetext{
la memoria' que como novela histórica o nueva novela histórica, aunque sin distanciarse demasiado de estas. La relación que ambas narrativas guardan con esa «memoria vivida» a la que se refiere Halbwachs, así nos lo ha indicado. En cualquier caso, estas 'escrituras de la memoria' podrían inscribirse dentro del marco general de la NNH, sin dejar de presentarse como un debate sobre la memoria 'reciente', pues mantiene vigentes implicaciones sociales, políticas, culturales y jurídicas con el presente. Se podría contra argumentar entonces que estas escrituras se posicionan como "testimonio" de un pasado común, como ha señalado el propio Juan Antonio Hernández respecto a su texto, pero ello implicaría un debate acerca de la veracidad de lo narrado al que la ficción no tiene necesariamente por qué responder.
} 
el «Ángel de la Historia», pero escriben en y desde el presente y al hacerlo construyen para el futuro un sentido posible del pasado. Las de la memoria son, pues, escrituras a contra fuego, hurgan entre las brazas, entre los restos carbonizados, convierten su huella cenicienta en palabras para que no todo se pierda. Con los restos del tiempo, construyen un relato, una historia potencial y verosímil sobre el pasado «en peligro de perderse para siempre», como advertía Benjamin.

Pero el fuego que ilumina y quema las narrativas de Duque y Hernández, convoca otro incendio, además que el del voraz paso del tiempo: ambas hacen referencia también y sobre todo al fuego de la pólvora y de la metralla, a la guerra, a la confrontación por el poder, a la lucha de clases, a la resistencia popular frente a las políticas represivas y, por ultimo, al terror del que el poder es capaz de revestirse para seguir siendo. Tiempos del incendio y Lo que va dictando el fuego refieren un momento convulso, una época de represión y persecuciones políticas, de resistencia y muerte: el incendio del Caracazo, nuestro infierno particular. Ambas narrativas convocan, ya desde sus respectivos títulos, esa doble metáfora del fuego — como transcurso del tiempo y como tiempo de guerra — que de algún modo marca una ruta de lectura e interpretación que aquí pretendemos seguir.

En cierto modo, ambas narrativas establecen la escritura como estrategia de salvaguarda de la memoria, como espacio propicio para reconstruir un pasado cuyo peso se deja caer todavía sobre el presente. Al mismo tiempo, la memoria aquí supone un ejercicio de reconstrucción de la pérdida y de reconducción del sentido de una época 'sinsentido'. Es decir, tanto en Tiempos del incendio como en Lo que va dictando el fuego, la memoria personal, íntima, privada, se funde y se confunde con la memoria colectiva, operando como ese «dispositivo colectivo de enunciación» que Deleuze y Guattari (1978) supieron ver en cierta literatura. Mediada por una experiencia personalísima, por la convivencia con un otro íntimo ahora ausente, la escritura convoca aquí una memoria del pasado común, pero también social y político. Ambas escrituras ficcionan un evento puntual -el asesinato de Gonzalo Jaurena- que opera como centro simbólico en torno al cual 
se estructura una memoria colectiva: la de la represión estatal durante los días del Caracazo.

Sin embargo, la forma cómo opera esa doble metáfora del 'tiempo en llamas' en las narrativas de Duque y Hernández no es, por supuesto, equivalente. La intensidad del fuego convocado no es la misma en uno y otro título y —aunque parece que me detengo en nimiedades - creo que hacer esta observación apunta en una dirección correcta y puede servir de guía a nuestra lectura de estas 'memorias de la violencia'. El fuego puede ser apacible o devorador; puede calentar la estancia en la que se está a gusto, leyendo o escribiendo — dos operaciones de la memoriao, por el contrario, desatar su naturaleza destructiva y desbastar todo alrededor. La distancia que va del incendio primitivo al fuego creador es la misma que media entre los textos de Duque y de Hernández. El primero parece trabajar todavía entre brazas ardientes, urgido por arrancarle papeles al incendio. El segundo, aunque ha atravesado el mismo infierno, trabaja calmo las cenizas. Así, la de Duque es una escritura fragmentaria, agujereada, de emergencia, mientras en la de Hernández se nos muestra poética, sosegada y se permite jugar con la retórica, preocuparse por las formas.

Tiempos del incendio trabaja sobre un pasado en ruinas, irrecobrable, casi intraducible: es una escritura que busca emerger de entre las mismas llamas de las que intenta recuperar una memoria popular, combativa, en resistencia, negada por el relato oficial. Lo-que-se-dice no ha sido dictado por el fuego, sino arrancado al incendio devorador del olvido. Lo que va dictando el fuego obedece en cambio a un ejercicio de recordación mucho más sereno, lo que se narra — aunque no menos doloroso- responde más a la reflexión que a la emergencia: se pasa revista al pasado, se lo re-construye, bajo la lumbre de la imaginación. Duque nos ofrece un texto incompleto: solo hay conversaciones, nunca descripciones, prácticamente no hay narración, no más de las que hace cada personaje; la escritura misma está a medio cribar, como si las voces flotaran en un espacio sin narrador. En cambio, la escritura de Hernández parece tener origen precisamente ahí donde el fuego cobija 
CATEDRAL TOMADA: Revista de crítica literaria latinoamericana / Journal of Latin American Literary Criticism La memoria entre cenizas: un diálogo im-pertinente entre Tiempos del incendio de José Roberto Duque y Lo que va dictando el fuego de Juan Antonio Hernández.

y da lumbre, alumbra el pasado, aunque se trate de un pasado convulso, doloroso, oscuro. Como él mismo señala,

Tengo la frágil esperanza de registrar todo lo que pueda de los gestos y las palabras de unos muchachos que vivieron a fines de los 80. Del esplendor de esas vidas, salvaje y puro, quedan algunas huellas como brasas dispersas a lo largo de una vasta intemperie nocturna. Quisiera creer que esas brasas no han dejado de susurrar, durante todos estos años, esto que ahora me propongo transcribir. Aunque sé que no hay testigo más extraño que el fuego. (Hernández 23)

Ambas escrituras, sin embargo, reconfiguran el recuerdo de la violencia, reelaboran el relato de un crimen político y lo sitúan, lo inscriben dentro del aparato simbólico de la memoria colectiva con una representación que es a un tiempo personalísima y social, como si ese personaje central y ausente a un tiempo que es Gonzalo Jaurena se constituyera en un símbolo de la época, en un bien común, es una herencia de todos. Bifurquemos entonces el sendero para hacer ambas lecturas.

\section{Memorias de una violencia colectiva: Tiempos del incendio, de José Roberto Duque}

"Ésa era la Venezuela-pueblo desatada y decidida a quebrar el sistema desde el movimiento estudiantil. Éramos unos carajos normales pero aguerridos. No éramos superhéroes: éramos el venezolano rumbero, romántico y jodedor en el trance de combatir un régimen monstruoso". (José Roberto Duque. Tiempos del incendio)

Tiempos del incendio pone en escena la reconstrucción de la memoria de Gonzalo Jaurena. Amigos y militantes políticos se reúnen alrededor del recuerdo 
de ese amigo interfecto para re-construir la historia de su militancia, de su lucha, de su resistencia, de su asesinato. Se trata de la "transcripción" de una o varias conversaciones en las que cada personaje irá ofreciendo al lector —un escucha indiscreto, en este caso- su testimonio particular acerca de Jaurena. Estas conversaciones se estructuran a partir de una investigación. Mariana reúne y entrevista a distintos personajes/testigos acerca de los hechos que precedieron y rodearon su muerte. El recorrido nos mostrará el lado más abyecto de la democracia: la política del crimen, el ajusticiamiento y exterminación del contrario. Mariana, imagen femenina del Virgilio de Dante, guiará a los testigos — y al propio lector- a través del infierno de esa memoria. Ella indaga, pregunta, contrasta, operando como acicate del recuerdo: «Yo vine a completar una investigación, a tomarles un testimonio que me parece importante» (Hernández 15), apunta. Y, unas líneas más adelante, agrega:

Aquí tengo esta cronología, estas copias de periódicos de la época, estos testimonios y estas preguntas. Yo quiero confrontar esta memoria ya recopilada con la memoria de ustedes. Ya encontré narradores, ahora voy por los protagonistas. (Duque 16)

La muerte convierte a Jaurena en una presencia muda; son otros los protagonistas de su propia historia, su voz se disemina en los otros para narrarlo. Su lugar, el lugar que le correspondía por derecho en el relato de su memoria, le es expropiado. Ángel, Óscar, Leonardo, José Alfredo, Mauricio —ex militantes de Los doce del patíbulo, el extinto grupo de choque en el que militó Jaurena-, pero también Héctor y Miriam, sus padres, y Mariale, su ex novia, están llamados a representarlo, a hablar en su nombre, a reconstruir para la memoria el relato colectivo de su vida, y de su muerte.

Como en la memoria de todo individuo, en la de Gonzalo Jaurena se conjugan acontecimientos personales y colectivos, eventos públicos y privados, hechos de carácter familiar, social y político. Sin embargo, al tratarse de un sujeto 
comprometido, militante de una organización que participó, en mayor o menor medida, en la insurrección popular de febrero de 1989, lo social y lo político no solo cobran aquí un protagonismo especial, sino que determinan la perspectiva desde donde se organiza y relata $s u$ memoria. El hecho de que ese ejercicio de memoria sea hecho por sus compañeros de militancia, subraya además el carácter social de esa memoria, que es a un tiempo la de Jaurena, la del grupo político al que pertenecía y la del país en su conjunto, porque alrededor del personaje interfecto de Jaurena se irá re-construyendo la serie de eventos socio-políticos que forman parte de la historia política venezolana.

En Tiempos del incendio, lo que se novela es precisamente la enunciación de una memoria individual que se funde en y con la memoria colectiva, nacional, mostrándosenos como dos caras de un mismo proceso de rememoración. Jaurena es entonces el muerto que habla, desde 'el-más-allá' del relato, contra el olvido, no solo de sí, sino de nosotros, de nuestro pasado común. Precisamente, lo que da estructura al relato, el eje principal, es esa ausencia suya: la excusa de su muerte obliga a los personajes a enunciar su memoria imposible que termina diseminada en la memoria de todos, al menos de todos los que, de una u otra manera, fueron víctimas de la represión. Eso no la convierte sin embargo en el relato lacrimoso de un duelo, al contrario. Lo que encontramos en sus páginas es parte de la memoria combativa y en lucha de los sectores populares frente a la violencia del poder. A medida que todos hablan, que todos recuerdan y narran ese pasado común, la ausencia que es Jaurena se puebla, se llena, y entendemos que lo colectivo lo arropa, lo completa, lo constituye como sujeto.

La ausencia de Jaurena, su imposibilidad de testificar, de concurrir ante el presente y dar testimonio, obliga a una reconstrucción de su memoria desde una alteridad que la asiste como testigo. Esa enunciación debe ser, está obligada a ser, colectiva y Tiempos del incendio se estructura en base a esta obligación, a ese deber, el deber de recordar-lo. Jaurena ya no está más, sino en la memoria de quienes lo recuerdan. Es en ellos, en el relato de esos protagonistas que dice buscar Mariana. El relato de la memoria común transpola la memoria individual y donde debería 
encontrarse solo el relato de un personaje, encontramos la memoria de un país, o al menos, de un episodio clave en la historia de ese país. Por eso el relato de los personajes, el relato construido entre todos, no recoge solamente la historia de Jaurena, la de su militancia y participación en los conflictos socio-políticos de la Venezuela de la década de los 80, o las circunstancias puntuales de su asesinato a manos de efectivos de la Policía Metropolitana. La historia, la memoria, el relato de la memoria de Jaurena se expande, se extiende, hasta darle forma, hasta conformar la memoria de cada uno de los que participan de esa construcción, rebelando el vínculo, las coincidencias pero también las diferencias, que los unían como grupo. Y a medida que las memorias de Jaurena y las del grupo se juntan, se superponen, se confunden, aparece la memoria del Caracazo, de los sucesos del Caracazo, narrados por testigos de primera mano, recordado por sus protagonistas.

Esa estrategia narrativa sirve a Duque para mostrar que «no hay memoria singular», como afirmaba Derrida (28). La memoria está más allá del sujeto, porque se vive colectivamente. Entendida como bien común, como proceso colectivo, la memoria sobrevive al sujeto, perdura más allá de él, resiste su muerte. Derrida es exacto al hablar de la muerte de un amigo y de su recuerdo: «Si la muerte le ocurre al otro y llega a nosotros a través del otro - explica-, entonces el amigo ya no existe excepto en nosotros, entre nosotros. En sí mismo, por sí mismo, de sí mismo, él ya no es más, nada más. Vive sólo en nosotros» (Derrida 39). Esa supervivencia del amigo muerto «en nosotros», faculta a ese «nosotros» para hablar en su nombre, en nombre del amigo muerto. Es lo que encontramos en Tiempos del incendio, un ejercicio de prosopopeya en la que los amigos y ex compañeros de militancia hablan en nombre de Jaurena, reconstruyen su vivencia, su experiencia, es decir, su memoria, pero para enunciar la memoria del suceso colectivo que da marco social a su asesinato. El crimen político termina siendo leitmotiv para narrar un pasado común, colectivo, nacional. Tiempos del incendio logra revestir el asesinato de un individuo de un poder simbólico tal que sintetiza la experiencia colectiva del terror que significó para Venezuela la masacre del Caracazo, asignándole a lo narrado la "autoridad" del testimonio. Esta estrategia narrativa conversacional involucra al 
lector, que no solo siente como si escuchara los diálogos, sino como si pudiera participar de estos, como si pudiera él mismo añadir algo a ese relato, a esa memoria que, en última instancia, le pertenece también.

Las declaraciones iniciales de Mariana sirven de aviso y ponen al lector en situación, es decir, pautan un posible contrato de lectura. Se trata de «completar una investigación», de «confrontar» la memoria heredada, oficial, inscrita en la prensa y los archivos judiciales, con la memoria «viva», primero, de militantes y compañeros de lucha; luego, de los familiares y amigos de la víctima. Esa operación de contraste entre la memoria oficial, pública, del poder y la memoria colectiva popular constituye el nudo sin desenlace de la trama. Sin desenlace, porque no hay cierre en lo que respecta al pasado, no puede haberlo; pero también porque la novela deja abierto el conflicto entre esa memoria pública institucionalizada, resguardada en documentos oficiales, en las hemerotecas de las empresas de información, y la memoria popular, que transita clandestina entre sus «protagonistas», sin acceso, las más de las veces, a las grandes redes de circulación del discurso. La novela misma es un escondrijo, un artefacto clandestino, un discurso de conspiración, que permite a la memoria popular colarse por entre las rendijas de la historia para contradecir la versión oficial y postular una verdad otra, distinta, alternativa, subalterna y, incluso, subversiva.

Precisamente, y esta es la lectura que nos interesa, la novela de Duque parece señalar que, en ese conflicto político-social, lo literario abre una «línea de fuga» a la máquina oficial de la memoria. Tiempos del incendio trama una historia de la violencia anti-maquínica que retorcerá los hilos del relato oficial emanado desde el poder, oponiéndole una memoria de y en resistencia. Esa memoria se irá conformando, construyendo, articulando, a partir de la narración, de la rememoración y de los testimonios de personajes menores, silenciados, excluidos, pero declarados en rebelión. Cada personaje comenta, reafirma, amplía, corrige o completa la narración del otro, constituyéndose en una pluralidad necesaria, en un sujeto colectivo que enuncia una memoria nacional, una mirada grupal sobre el pasado común, desde la que se postula que el ejercicio de la memoria es por 
naturaleza - por la naturaleza misma del texto también- colectiva. Lo que queda claro, lo que parece quedar en claro, al menos, es que «hacer memoria» obliga a un esfuerzo común.

Los personajes de Duque narran ese testimonio/memoria desde una pluralidad necesaria, pues lo que se recuerda se vivió - y casi podríamos decir se percibió- colectivamente.

Nosotros no éramos unos carajos que creyéramos en la pureza sino más bien los raros y los locos de la partida. Un grupo de militantes de base que en lugar de meternos por el carril de la disciplina partidista comenzamos a juntarnos más seguido con estos otros locos desaforados, eso que llamaban Desobediencia. (Duque 21)

La mirada grupal es aquí imperiosa, necesaria, por dos razones. En primer lugar, porque solo el grupo puede re-construir como memoria un acontecimiento colectivo, percibido como «bien común». El relato "testimonial” de cada uno de los personajes completa, complementa y da contexto al de los otros, concatenándose como elementos de un mismo discurso sobre el pasado común. Esa relación dialógica no niega las contradicciones, las réplicas, la contra-argumentación; al contrario, fomenta el debate, la diatriba sobre lo real. Duque parece llevar a escena la afirmación teórica de Maurice Halbwachs sobre la memoria: «se puede hablar de memoria colectiva - explicaba el francés - al evocar un acontecimiento que ocupaba un lugar en la vida de nuestro grupo y que hemos considerado, que consideramos todavía hoy al recordarlo, desde el punto de vista de ese grupo» (79). La interconectividad de las memorias individuales cobra unidad discursiva. La construcción narrativa de Tiempos del incendio parece perseguir el ideal imposible de Halbwachs según el cual, para «reconstruir integralmente el recuerdo de cierto acontecimiento, debería reunir todas las reproducciones deformadas y parciales de las que es objeto entre los demás miembros del grupo» (101). Pero, en segundo lugar, solo esa pluralidad enunciativa, ese «nosotros» que habla, puede oponerse, 
como sujeto autorizado y de resistencia, al poder, a la enunciación única, hegemónica, que el poder busca imponer sobre el pasado común. Sin esa pluralidad del relato, no hay memoria colectiva.

Esta segunda razón permite recordar y entender el Caracazo no solo como un evento traumático, sino también como expresión de la lucha y de la resistencia popular. Su recuerdo, su memoria, su rememoración, reivindica ese carácter subversivo. El relato de los sucesos se desdramatiza en la narrativa de Duque, al tiempo que se cuece como memoria épica ${ }^{5}$.

Los que nos reuníamos en la UCV éramos gente de barrio, proletarios, pobres e hijos de gente pobre, y nos sentíamos dueños de esa violencia redentora, de la violencia revolucionaria, la violencia clasista: nosotros, los pelabolas, los cimarrones de todos los tiempos. De pronto se aparecen estos coños de familias burguesas y con pintas de burguesitos: Ángel, José Alfredo, Fermín, Gonzalo, y por supuesto que hubo un choque, una confrontación natural ahí. Creo que nunca discutimos eso frontalmente, pero el comentario se escapaba de vez en cuando: esa arrecherita de nosotros los negros pataenelsuelo que al principio veíamos con sospecha a estos camaradas sifrinos, intelectualosos, que venían de una universidad burguesa y tal [...] Pero llegado el momento resulta que todos echaban coñazos y tiraban piedras y se caían a tiros igual que uno... (Duque 21)

Lo declarativo ha desplazado aquí lo narrativo. Cualquier intento narrativizador ha cedido ante el diálogo, privilegiando el testimonio de cada uno de los personajes por sobre la interpretación que pudiera adjudicarse al narrador, que se diluye hasta desaparecer, o hasta convertirse solo en elemento organizador del

\footnotetext{
5 Es necesario señalar que este no es el primer trabajo de José Roberto Duque al respecto. En Salsa y control (1996), Duque había abordado ya el carácter rebelde de la memoria popular de El Caracazo. Este trabajo forma parte de una investigación más amplia, en la que analizamos también ese otro texto de Duque.
} 
discurso. Ese narrador podría haber sido Jaurena. Ambas figuras aparecen tachadas, borradas, igualadas en su ausencia atroz. Ambos operan aquí como un ente abstracto y su única función parece ser la de dar orden al discurso de los personajes. Nada se narra sino lo que narran los testigos; nada se describe, sino aquello que fluye directamente desde la memoria de cada personaje.

Es el narrador — explica Ricardo Piglia — «el que tiene la posibilidad de definir la verdad interna de un texto» (136). Su ausencia, o el simulacro de su ausencia, es decir el diálogo directo, «crea la ilusión de que no existe nadie más que los que están hablando, y la superposición de documentos y materiales —como conversaciones telefónicas o informes policiales - [presentes también en la novela de Duque] parecen venir de lo real mismo e intentan reconstruir la narración a partir del montaje y la yuxtaposición de materiales diversos» (Piglia 136). Hablamos por supuesto de un simulacro, de una estrategia de representación de la ficción misma para desdibujar la figura mediadora del narrador y hacer ver como si la realidad pudiera expresarse sin intermediarios. Tiempos del incendio opera así como un verdadero «dispositivo colectivo de enunciación»(Deleuze y Guattari) de la memoria. Ese es, como sugiere Piglia, «el lugar de la política», es decir, del otro, en la literatura. «La verdad — dice el argentino — tiene la estructura de una ficción donde otro habla. Hay que hacer en el lenguaje un lugar para que el otro pueda hablar. La literatura sería el lugar en el que siempre es otro el que habla» (Piglia 124). Tiempos del incendio abre ese espacio ficcional a «lo político», es decir al otro, a $s u$ verdad. No otro puramente retórico, sino el otro histórico, el desplazado, el desclasado, el pobre, y ello es así aun cuando esa aparición sea ficcional. La novela opera como espacio/medio para que una verdad distinta a la social y culturalmente impuesta, sea dicha: la verdad otra de la memoria popular. El pasado reaparece aquí dicho desde una perspectiva anti-hegemónica para contradecir una Verdad que el poder instituye o pretende instituir como única.

La conjunción de las visiones particulares, individuales, de los miembros del grupo, su recuerdo/relato del episodio pretérito común, propicia una articulación y un vínculo profundos que los constituye en expresión de la memoria 
colectiva. En este sentido, se entiende que la constitución como grupo es necesaria, pero no suficiente. El grupo debe distinguirse entre la multitud, autoafirmarse, dotarse de la autoridad necesaria para constituirse en, y autorizarse como, narrador de sí mismo y de su propia memoria. En el relato de Duque, ese sujeto colectivo se autodenomina «Los doce del patíbulo» y su rasgo distintivo, su identidad grupal, se construye en torno a su radical posicionamiento político, al debate constante sobre su contemporaneidad, a una militancia que persiste en el tiempo, cuya memoria compartida lo consolida, lo dota de identidad y ser.

Además, esa posición vanguardista, en la primera línea de combate, le confiere a los personajes cierta 'autoridad' para dar testimonio. Cada uno se presenta como testigo de excepción, como protagonistas:

Mariana: ¿Ustedes eran especímenes de lo que el rector Chirinos llamó la Generación Boba?

Ángel: No, éramos una anomalía, un pedazo de historia que dio un salto y causaba ruido y distorsiones. En un país que no se decidía a dejar de ser adeco o copeyano, éramos los bichos raros, la ultraizquierda. "Los peligrosos", como dice el poema de José Alfredo. En ese país estupidizado fuimos un anuncio, porque nuestros actos de violencia callejera organizada informaban que la sociedad estaba a punto de romper con la estupidización. Éramos un país en etapa germinal. No lo sabíamos entonces; podemos leerlo ahora, a la distancia. (Duque 27-28) ${ }^{6}$

${ }^{6}$ El personaje de Mariana hace referencia al Doctor Edmundo Chirinos quien, durante su desempeño como rector de la Universidad Central de Venezuela, hizo referencia a los estudiantes de los años 80 como «la generación boba», pues a su juicio estos carecían de iniciativas e ideales políticos para enfrentar el modelo democrático impuesto por las élites. El comentario marcó distancia entre Chirinos y el movimiento estudiantil, que hasta el momento se habían respaldado mutuamente. Más adelante, el rector Chirinos se vio implicado en lo que se conoce como «la masacre de Tazón»: «El día 19 de septiembre [de 1984] los estudiantes de Agronomía y Veterinaria [del núcleo de Maracay de la UCV] tomaron cuatro autobuses de la Dirección de Transporte de la universidad. En ellos viajaba un número superior a las cuatrocientas personas a fin de ingresar al recinto del Consejo Universitario para exponer sus peticiones. Edmundo Chirinos recibió la noticia en Caracas, y — como apuntó luego - tomó la decisión personal de llamar al viceministro de Relaciones Interiores Cesáreo Espinal Vásquez para que impidiera el paso de los 
En ese contraste entre una y otro relato sobre el pasado, la exterioridad de la memoria oficial se ridiculiza, pero se acepta también como propia. El entorno no es ajeno, aunque se lo combata. El grupo no escapa al contexto socio-cultural que lo envuelve, que lo oprime incluso, pero del que sigue sintiéndose parte. En la novela, el debate al respecto es ilustrador:

Óscar: [...] El mercado internacional del disco, ese ranking de las canciones más oídas y los discos más vendidos, da cuenta más o menos del estado espiritual de la nación en aquellos meses aciagos: Devórame otra vez, Lalo Rodríguez; Qué bello, Kiara; Insaciable compañero, Eddie Santiago; Tan enamorados, Ricardo Montaner; Sacúdete, nena, Roberto Antonio; Cuarto de hotel, Bonny Cepeda y Papachongo, Los Melódicos. Que siga la tragedia pero que no se detenga la convocatoria al fornicio, o al menos a su simulacro bailable.

Mariana: Ah, no me jodan: ¿es que los comunistas tenían algo contra el sexo? ¿Qué tenía de malo que estuvieran de moda esas canciones?

Ángel: ¡Nada! Pero era un poco desolador, más bien desesperante, que mientras había masacres y represión por todas partes, el país siguiera hipnotizado bailando detrás de esas letras facilonas y esos ritmos...

Óscar: A mí sí me gustaba todo lo que echaba la radio para la calle. Y el culo de la Fullop. Sociedad descompuesta: música descompuesta, arte descompuesto, mal gusto y que siga la fiesta. Una Venezuela en aquel estado de conmoción y deterioro tenía que producir esas manifestaciones artísticas deformadas. Caricaturas del arte. (Duque 36)

estudiantes a la capital. Los autobuses fueron detenidos en la alcabala de la GN en Hoyo de la Puerta y sus pasajeros conminados a desalojar las unidades para ser revisados. Luego de dos horas de detención, los estudiantes decidieron arrancar los autobuses y romper el cerco impuesto por los militares, lo que produjo el ametrallamiento de las unidades [...] Un número superior a treinta personas resultaron heridas, veintidós de suma gravedad» (Rada y Contreras 39). 
CATEDRAL TOMADA: Revista de crítica literaria latinoamericana / Journal of Latin American Literary Criticism La memoria entre cenizas: un diálogo im-pertinente entre Tiempos del incendio de José Roberto Duque y Lo que va dictando el fuego de Juan Antonio Hernández.

La banalidad de la cultura impuesta desde los mass media y desde el aparato cultural todo, contrasta con la crudeza de la crisis económica, social y política del país; pero, sobre todo, con los altos niveles de represión. Así lo expone Ángel a Mariana:

Después del Sacudón, la masacre y desaparición de miles de venezolanos, el país tornaba a eso que la sociedad burguesa llama "normalidad". Quienes estábamos activos en la Universidad sostuvimos muchas discusiones, algunas de ellas muy amargas, sobre la pertinencia de tratar de mantener el clima de agitación en las calles. No sé si por ingenuidad, por voluntarismo o porque los acontecimientos estaban demasiado frescos, pero el caso era que invertíamos tiempo y energía en discutir un fenómeno que escapaba a nuestras posibilidades de acción y organización: ya lo que estaba sucediendo en el país no iba a ser potenciado ni inhibido por el movimiento estudiantil o por vanguardia alguna. Todavía estaban muy frescos los efectos del Sacudón, la masacre contra todo un pueblo, la persecución contra gente del movimiento estudiantil, los cacerolazos y las torturas contra la gente del 23. El punto era cuán necesario o recomendable era tratar de encender una candela después de apagado el gran incendio del siglo: el Caracazo. (Duque 84)

Precisamente, la posición que se atribuye a Jaurena busca mostrar las contradicciones políticas internas de las organizaciones populares, en general, y del movimiento estudiantil, en particular. Pero también, por la otra, la radicalización de la protesta a la que estaban dispuestos los sectores populares. Las consecuencias del Caracazo no fueron la normalización y la vuelta a la rutina. Aunque en muchos casos se impusiera la cautela por temor a un recrudecimiento de la represión, la verdad fue que durante los meses que siguieron al Caracazo las calles continuaron encendidas. Podríamos incluso decir que El Caracazo condujo a una repolitización, sino de toda, al menos sí de grandes sectores de la sociedad venezolana. El 
personaje Jaurena de Tiempos del incendio es símbolo de ese posicionamiento radical de algunos líderes sociales y estudiantiles:

Gonzalo defendía una posición que a muchos nos parecía ofensiva o desproporcionada, porque nos aludía, pero al final resultaba la más honesta: decía que quedarse gravitando en la Universidad era apoyar una forma de protesta más frívola que auténticamente revolucionaria. Veía un dilema por resolver: o nos quedábamos en la Universidad o nos juntábamos con el pueblo desbordado. Él decidió personalmente anotarse con la segunda opción. (Duque 84)

No es necesario citar los pormenores del crimen, que la narración deja a los padres y a la novia de Jaurena, más pertinentes para contar el lado más dramático del relato. Lo que sí es oportuno señalar es que Tiempos del incendio logra conjugar la memoria política del grupo con la memoria privada, íntima, de la familia. El testimonio familiar apunta también a la desdramatización del evento criminal en sí, para apostar a su revalorización simbólica. El relato de Héctor Jaurena, padre de Gonzalo, busca un centro más allá del dolor y del duelo y lo encuentra en la obstinación del viejo por obligar al Estado a juzgarse a sí mismo y aplicar la justicia, condenando, por lo menos, al policía que asesinó, por la espalda y en el suelo, a su hijo:

No quise para mi hijo ningún honor que él hubiera despreciado por tratarse de rituales burgueses o desproporcionados. Lo sepultamos en el Cementerio General del Sur, en una tumba pobre al lado de los pobres de Caracas. Mi único homenaje ha sido llevar el caso judicial hasta el punto en que la justicia burguesa funcione para castigarse a sí misma. (Duque 87) 
La memoria privada y la memoria popular se conjugan aquí para oponerse, con la misma fuerza ética, a la memoria oficial. Desde lo popular se reivindica una memoria épica del Caracazo, desde lo familiar, impera el reclamo de justicia. Esa memoria no se contenta con recordar, es decir, no se construye aquí una memoria museografiable, inactiva, inerme o, como la definiría Todorov, literal. El relato del pasado no es sometido aquí a un proceso de canonización ni es convertida en objeto de culto, todo lo contrario. Ese pasado se sabe y se entiende como construcción discursiva y es, en tanto tal, perfectible, es decir, está expuesto a intervenciones, manipulaciones, tergiversaciones; pero también al esclarecimiento y a la justicia. Es la memoria de los vencidos, de las víctimas de una violencia de Estado que se hizo cotidiana y nos condujo al terror. De ahí el esfuerzo por construir un relato alterno, incluso subalterno, de los acontecimientos pretéritos que reclaman una revisión y un sentido en y desde el presente. Ese relato múltiple, propuesto como memoria popular, interviene en el espacio público en el que distintos discursos pugnan por otorgar sentido al pasado, para postularse como verdad otra que la oficial, fundamentada en los vínculos afectivos, familiares y políticos que los personajes guardan con Gonzalo Jaurena. En esa dirección, no opera aquí una «memoria literal», en la que «el acontecimiento recuperado permanece ‘intransitivo' y no puede conducir 'más allá de sí mismo' (Todorov 50), sino que apunta a una memoria en movimiento, combativa, en pugna con el secuestro del pasado y las operaciones de asignación de sentido del poder.

$\mathrm{Si}$ seguimos los planteamientos de Todorov, podemos percibir las operaciones de rememoración de Tiempos del incendio como postulantes de una memoria ejemplar, dentro de la que, «sin negar la singularidad del suceso», se toma la decisión de utilizarla «como una manifestación entre otras de una categoría más general» y hacer uso de ella «como de un modelo para comprender situaciones nuevas, con agentes diferentes». Es decir, la memoria del pasado puesta al servicio del presente — del futuro también—, pero sobre todo de la justicia, o de una noción de justicia que linda con la ética y exige el cese de la impunidad. Este trabajo de memoria persigue no solo neutralizar los efectos traumáticos del suceso, sino abrir 
«ese recuerdo a la analogía y a la generalización», entrando de lleno en la «esfera pública» y convirtiendo el relato del pasado «en principio de acción para el presente» (Todorov 50-51).

En Tiempos del incendio, la memoria se desobjetiviza y se postula no solo como versión plausible del pasado, sino como herramienta política y de reivindicación que opera en y desde el presente. Desde nuestra particular perspectiva, vemos en estas escrituras de la memoria una especie de documentos apócrifos en los que sobrevive, opuesta a la versión oficial, una memoria popular, clandestina, de la historia reciente. La escritura — el libro mismo - se convierte en artefacto de lucha y se inscribe en la red social significante como instrumento de resistencia. Por supuesto, este tipo de escrituras transitan circuitos discursivos distintos a los de los archivos oficiales y los grandes discursos. Los primeros se oponen a los segundos, ciertamente, pero desde posicionamientos enunciativos, ideológicos y políticos claramente desiguales. Mientras los documentos públicos copan los círculos burocrático-judiciales de la memoria oficial, los estantes de las hemerotecas públicas y privadas y hasta los textos de Historia, la memoria popular sobrevive y circula, de forma más o menos encubierta, en los suburbios del sistema simbólico, algunas veces — como en este caso- travestida en novela.

\section{Pasado, amistad y muerte: el duelo por la memoria en Lo que va dictando el fuego de Juan Antonio Hernández}

\begin{abstract}
"En los pactos que los hombres hacemos con el infierno siempre nos toca un demonio en particular. El mío es el de las noches sin dormir, pariente de los que cuidan los accesos a la memoria o el olvido". (Juan Antonio Hernández. Lo que va dictando el fuego)
\end{abstract}

a) La memoria afectiva 
$\mathrm{Si}$, como vimos con Ricoeur, impera una diferencia fundamental entre recuerdo y memoria, en tanto el primero está indisolublemente asociado a una afección (cuasi) involuntaria, mientras la segunda es consecuencia de un esfuerzo racional y consciente del pensamiento, no podemos asegurar sin más se trate de condiciones excluyentes. Al contrario, no hay razón alguna que niegue la existencia de un principio afectivo en los trabajos de memoria, e incluso me atrevería a conjeturar que difícilmente se podría iniciar una reconstrucción seria y documentada del pasado, sin algún elemento propiamente afectivo. Por más que pertenezca al ámbito de lo social, el pasado colectivo no abandona los terrenos del yo, de los afectos y las afecciones del yo. La relación es inversamente proporcional: lo social afecta tanto la esfera privada como el sujeto la representación del orden social. El vínculo que el sujeto mantiene con el pasado común o colectivo es también, en buena medida, personal, afectivo, íntimo.

Precisamente, una de las primeras características que llama la atención de Lo que va dictando el fuego es esa fuerte conexión emotiva-intelectual que la novela establece como base fundamental para hacer posible el relato del pasado. Las confesiones más íntimas se entrelazan y cruzan con los argumentos de la razón, la experiencia personal se sustenta con datos históricos, las anécdotas particulares se referencian con alusiones a figuras clave de la literatura o el pensamiento, de José Martí a Walter Benjamin. Esta construcción narrativa apunta y pone en el centro del debate que el ejercicio mismo de recordar y representar el pasado obedece tanto al esfuerzo racional del pensamiento y la investigación, como a los afectos que el sujeto mantiene con $s u$ historia. Esta doble naturaleza de la escritura memorialista no solo posibilita sino que obliga a la memoria a traspasar continuamente la porosa frontera que separa lo individual de lo colectivo, lo público de lo privado. Ese ejercicio de tránsito, de ida y vuelta entre lo personal y lo colectivo en el que opera la memoria, ese punto de acercamiento y contacto extremo que rosa la fusión hasta el límite de la confusión, perfila la propuesta ética y estética que Hernández nos ofrece en Lo que va dictando el fuego y es central a nuestra lectura de su novela. 
En el aspecto más formal, la escritura se presenta como transcripción del pensamiento, de un relato íntimo, personalísimo, que se exterioriza y se hace público. Lo que va dictando el fuego guarda casi siempre la forma de un monólogo interior que el narrador dirige directamente a Gonzalo Jaurena, el amigo interfecto al que se pone al tanto - como si tal fuera posible - de los acontecimientos públicos y privados que precedieron, rodearon y siguieron a su asesinato. Ese monólogo interior —íntimo, privado — va dirigido en primera instancia al amigo muerto, pero se inscribe sin embargo en el terreno social. La novela actúa así como documento público, y pone en circulación tanto una memoria - popular, rebelde, antihegemónica - como una denuncia, es decir, un reclamo de justicia. Una justicia que en este caso invoca un más allá jurídico, una justicia histórica, digamos. Lo que se busca no es ya el castigo al asesino —el policía que asesinó a Jaurena fue finalmente castigado, como verificará el relato_-, sino al propio sistema.

Como toda escritura sobre el pasado, Lo que va dictando el fuego se inscribe a un tiempo en el doble contexto de la enunciación y de lo enunciado. En el ejercicio escriturario se hace

inevitable la marca del presente sobre el acto de narrar el pasado, precisamente porque, en el discurso, el presente tiene una hegemonía reconocida como inevitable y los tiempos verbales del pasado no quedan libres de una "experiencia fenomenológica" del tiempo presente de la enunciación. (Sarlo 64-65)

La novela documenta entonces esa memoria negada, oculta hasta entonces. De ella y con ella, emerge como presente, agencia el relato de ese pasado desde un presente que se interroga sobre los acontecimientos que lo conforman, su pertinencia, su sentido histórico, pero también y sobre todo su actualidad. No precisamos encontrar una representación fidedigna de la represión política durante los eventos del Caracazo, ni siquiera sobre la muerte de Gonzalo Jaurena, central en la trama de Hernández. La preocupación por los hechos del Caracazo en Lo que 
va dictando el fuego es actual y de lo que se trata precisamente - usando la excusa de "poner al día" al narratario fantasma del relato_- es de recuperar para el presente el sentido de ese acontecimiento. «La rememoración del pasado (que Benjamin proponía como la única perspectiva de una historia que no reificara su objeto) no es una elección sino una condición para el discurso, que no escapa de la memoria ni puede librarse de las premisas que la actualidad pone a la enunciación» (Sarlo 66). Si es cierto, como pensamos, lo que señala Sarlo, no es menos importante precisar que esa "marca inevitable del presente" en la narración sobre el pasado es justamente lo que hace posible la reflexión sobre los eventos pretéritos. Solo el transcurrir del tiempo posibilita esa reflexividad del pensamiento y de la escritura sobre el pasado.

El arte «ha demostrado que la exploración no está cerrada sólo dentro de los límites de la memoria, sino que otras operaciones, de distanciamiento o de recuperación estética de la dimensión biográfica, son posibles» (Sarlo 58). Ese elemento estético de recuperación del pasado en la novela de Hernández se sostiene sobre el vínculo afectivo-emocional que el narrador mantiene con el narratario interfecto al que está dirigido el relato. El entramado afectivo de las operaciones de la memoria recobran aquí — para sí y para todos_ ese sentido inicial con el que los griegos asociaban el recuerdo a las funciones del corazón. Recordar, ya se sabe, proviene del griego recordis, que podría traducirse como volver al corazón. Lo afectivo no tiene por qué ser visto aquí solo como aquello por lo que se tiene simpatía, sino como todo lo que de un modo u otro "nos afecta", en general.

Vimos antes que son precisamente los eventos traumáticos los que demandan mayor atención, pues estos conllevan profundas dificultades para «constituir su sentido y armar su narrativa» (Jelin 28). Lo traumático es, precisamente, eso oscuro que no-se-puede-contar, que no puede materializarse en lenguaje, relatarse con palabras y compartirse como experiencia. Jelin y Ricoeur coinciden en establecer, desde ahí, una relación entre el «trabajo de duelo» explicado por Freud y el «trabajo de memoria», transfiriendo nociones y experiencias psicoanalíticas del orden estrictamente personal a lo colectivo. 
Incluso, para Ricoeur, «[s]e puede dar un paso más y sugerir que es en el plano de la memoria colectiva, quizás más aún que en el de la memoria individual, donde adquiere todo su sentido la comparación entre trabajo de duelo y trabajo de memoria» (109). Según entiende Jelin, la situación límite que implica un evento traumático conlleva un doble peligro: «el de un "exceso de pasado" en la repetición ritualizada, en la compulsión que lleva al acto, y el de un olvido selectivo, instrumentalizado y manipulado» (14). Los trabajos de la memoria operarían precisamente sobre estos eventos traumáticos y estarían orientados a su superación:

En el plano colectivo, entonces, el desafío es superar las repeticiones, superar los olvidos y los abusos políticos, tomar distancia y al mismo tiempo promover el debate y la reflexión activa sobre ese pasado y su sentido para el presente/futuro [...] Esto implica un pasaje trabajoso para la subjetividad: la toma de distancia del pasado, "aprender a recordar". Al mismo tiempo, implica repensar la relación entre memoria y política, y entre memoria y justicia. (Jelin 16)

El ejercicio de rememoración pasa aquí no solo por la urgencia de superar el trauma, sino también y sobre todo por el hecho de extraer ese episodio del ámbito puramente privado y abrirlo a la experiencia colectiva. Esta irrupción del relato personal en el espacio público, activa la doble tensión entre memoria y política, por una lado, y entre memoria y justicia, por el otro, como apuntaba Jelin en la cita anterior. El relato de la memoria cumple a la vez una promesa y un deber, la promesa de recordar al amigo, el deber de recordar que aquél fue víctima de la violencia de Estado y exigir justicia en consecuencia. Esa es, precisamente, la operación que vemos cumplirse en la narrativa de José Antonio Hernández: Lo que va dictando el fuego extrae del ámbito puramente privado esa memoria particular del asesinato de Jaurena, para re-incorporarla, simbólicamente, en el imaginario y la memoria colectivos; pero también en el espacio público del Derecho y de la Justicia. Recordarlo — como amigo y como víctima—, encarna en sí mismo un 
gesto político, pero es también, al mismo tiempo, un acto de justicia: recordar a las víctimas les restituye un lugar que acaso les había sido negado. El gesto político consiste en el hecho mismo de que el relato de esa memoria irrumpa e interfiera el discurso público sobre ese pasado, para enunciar una memoria distinta de la oficialmente impuesta. El acto de justicia adviene del hecho mismo de recordarlo, pero también de denunciar la impunidad del crimen. Si, como sugerían Deleuze y Guattari, no hay que preguntarse qué quiere decir un libro, sino con qué funciona, «con qué otra máquina, la máquina literaria puede ser conectada, y debe serlo para que funcione» (11), Lo que va dictando el fuego se une, debe ser unida «para que funcione», a la política y al derecho. La política y el derecho, vinculados siempre al ejercicio de memoria, son los dispositivos externos que activan el sistema de flujos de sentido en la novela de Hernández.

b) La memoria funeraria y el sentido político de la amistad

Memorias para Paul de Man, de Jaques Derrida, es, a un tiempo, una reflexión teórica sobre la memoria funeraria y un ejercicio de recordación de un amigo interfecto. En ese sentido, el trabajo derrideano puede servirnos como herramienta para leer ciertas claves de funcionamiento de Lo que va dictando el fuego. Como vimos, para Derrida, la muerte del otro - cercano, amigo- opera una introspección de ese otro en nosotros, nos hacemos uno con él. El deudo hereda la memoria del amigo muerto y, en este sentido, toda escritura sobre el prójimo difunto es en cierto sentido parte de $s u$ legado, una herencia que ese otro nos lega y que se resuelve, se expresa, en memoria del otro, aun cuando esa memoria sea una expresión de dolor, de duelo por la ausencia misma, por la muerte misma, de ese otro próximo, cercano, prójimo.

El muerto está confiado - y confinado_ a la sola memoria de los vivos. No осира otro lugar que el de la enunciación y el recuerdo de sus otros. Ese proceso de interiorización del otro ausente, explica Derrida, es el «origen de la ficción», al menos de la ficcionalización del otro: 
[D]esde Freud, así es como a menudo se describe el "trabajo de duelo" "normal". Supone un movimiento en que una idealización interiorizante toma en sí misma o sobre sí misma el cuerpo y la voz del otro, el rostro y la persona del otro, devorándolos ideal y cuasi literalmente. Esta interiorización mimética no es fictiva; es el origen de la ficción, de la figuración apócrifa. (Derrida 45. Énfasis nuestro)

El peso del otro en nosotros, su memoria, su presencia viva, obliga: recordarlo es un deber, una deuda pendiente; de ahí el duelo, el período de duelo que guardamos al prójimo. Su muerte fija una deuda que a veces puede ser solo de recordación, pero que en otras ocasiones involucra a la justicia, como cuando esa muerte es causa directa de la acción de un tercero, pero sobre todo cuando se trata de un crimen político. Lo-el-fuego-dicta en ese caso es la puesta en autos de ese proceso: llevar la memoria de ese crimen al terreno de lo social y de lo jurídico, porque la naturaleza misma del crimen político es colectiva. En esos casos, la memoria es «un deber [...] y una necesidad jurídica, moral y política» (Sarlo 62). Hablar por el otro, dar testimonio de él, en su nombre, representarlo es, a un tiempo, un gesto simbólico, un homenaje y un acto de justicia.

Volvemos sobre la imposibilidad de una «memoria singular», que ya vimos en la novela de Duque. Lo que estas escrituras de la memoria parecen decir, más allá de lo narrado, es que parece imposible lindar la memoria subjetiva, como si esta no se dejara circunscribir a un ámbito puramente personal, como si incluso el recuerdo más íntimo estuviera atravesado por la presencia del otro. Esta imbricación opera en ambos sentidos. Es decir, si la memoria va dirigida al sí mismo, involucra la presencia del otro. Pero si el objeto de recordación es el otro, ello implica a su vez un ejercicio auto-recordación. Jelin dialoga con Ricoeur al respecto: 
"Nunca estamos solos" — uno no recuerda solo sino con la ayuda de los recuerdos de otros y con los códigos culturales compartidos, aun cuando las inmersos en narrativas colectivas, que a menudo están reforzadas en rituales y conmemoraciones grupales (Ricoeur, 1999). Como esos marcos son históricos y cambiantes, en realidad, toda memoria es una reconstrucción más que un recuerdo. (Jelin 20-21)

Ello se acentúa en el caso de la memoria póstuma, de la memoria funeraria, por eso Derrida la define como un ejercicio de prosopopeya (1998). La amistad que media entre difunto y deudo, es el lugar en el que se confunden sus historias y la vida misma se presenta como una experiencia compartida. La pérdida del otro, clave en la escritura de la memoria funeraria, obliga a darle voz a un sujeto ausente y ese ejercicio de prosopopeya supone un relato agujereado, incompleto, impreciso. Queda del narrador, exponer o escamotear las fisuras de ese discurso.

En Lo que va dictando el fuego, la escritura insiste sobre ese ejercicio de búsqueda y las imprecisiones son parte de la estrategia discursiva y estética de representación del pasado común. Aquí, la memoria remueve, tantea, ensaya y todos esos movimientos van dando forma a la escritura. El narrador expone sus dificultades para precisar el principio del relato, una escena inicial — digamosque se presenta siempre como inestable, escurridiza, fugaz: «Tengo que retroceder la película. Buscar el momento en que te conocí, mezcla imposible de Lautremont con Raúl Sendic, uruguayo loco y maldito» (Hernández 25). Si lo que se va a acometer es la tarea titánica de reconstruir la memoria del otro, recuperar el momento del encuentro es necesario para dar inicio al relato, pero ese momento huye, se escabulle, se resiste y es esa búsqueda lo que se narrativiza. En ese juego se va definiendo, perfilando ese narratario interfecto, silente, mudo.

El otro termina siempre por escapar. La ausencia se llena por momentos de palabras, pero luego adviene otra vez el vacío. Cuando el narrador anuncia que va a narrar la historia de $s u$ amigo, el adverbio posesivo cobra un peso definitorio de la narración toda, que obliga a la presencia o re-aparición del sí mismo. El «yo» 
que esconde el posesivo «mi» — de «mi amigo»— traza el mapa del relato de la memoria fúnebre, porque ese otro al que (se) alude, ya no está más. De esta forma, para reconstruir ese momento inicial del encuentro, el narrador está obligado a volver siempre sobre sí, el otro ya no está más para aclarar la duda, los pormenores de su propia historia: la memoria del otro se ha hecho inseparable de la propia: «a lo mejor tengo que irme más lejos: hasta el instante en que empecé a meterme en política y terminé por incorporarme al Partido» (Hernández 25). Para recuperar al otro, la única memoria que queda es la propia. Esta oscilación permea y marca el relato la escritura de la memoria íntima: lo biográfico es inseparable de lo autobiográfico, y viceversa.

Las imprecisiones se repiten, la escritura tantea en el vacío de la memoria, lucha contra el olvido: «Ahora trato de recordar el momento exacto en que comenzamos a hablar, a conversar de política, y no puedo precisarlo» (43-44), insiste el narrador. Sin embargo, lo que realmente importa no es ese vano, imposible esfuerzo de precisión, sino el ejercicio de dialogar con ese pasado, de actualizarlo y darle, de algún modo, continuidad, obligándolo a ser partícipe del presente. El narrador no le habla en pasado a Jaurena. Lo interpela en presente, desde el presente, como si él estuviera ahí, con él, acompañándolo en el ahora de la narración, de la conversación: El narrador sigue con Jaurena un diálogo imposible:

Imagínate, uruguayo, el fragmento de $\mathrm{Hegel}^{7}$ como un relato mítico, un cuento sobre los orígenes de todas las cosas humanas, narrado por una voz muy antigua e insomne, cansada de tanto horror, murmurando sola, mientras los otros duermen, alrededor de una fogata que se apaga, en medio de una vasta intemperie nocturna. (Hernández 45)

${ }^{7}$ El narrador hace referencia al fragmento en el que Hegel explica la dialéctica del amo y el esclavo, en Fenomenología del espíritu, para aplicarla a la realidad venezolana, aunque, como veremos, unas pocas páginas más adelante, ésta le resulte insuficiente y deba añadir nuevos elementos. 
El esfuerzo por continuar una conversación íntima, amistosa, pero también filosófica y política sobre la realidad, la interpelación directa al ausente, subraya ese esfuerzo de actualización, como si se pudiera superar la muerte, como si la palabra fuera capaz de romper esa frontera imposible para volver a hablar con el otro para siempre perdido. Para que esto sea posible, la introspección de la que nos habla Derrida debe ser completa. La ficción ha nacido de esa introspección para reparar lo irreparable, para subsanar el hecho cierto de la muerte del otro y hacerlo partícipe de las propias cavilaciones sobre el presente. La conversación, siempre con tintes intelectuales, sobre lo político, sobre las circunstancias socio-históricas, se postulan aquí como un elemento central de la amistad entre el narrador y su narratario interfecto. Su recuperación, su actualización, su prosecución, solo son posibles porque derivan de ese proceso de internalización y ficcionalización del que Derrida nos habla en Memorias para Paul de Man. Aparece ahora en el horizonte el elemento que nos hemos trazado como objetivo desde el principio: la amistad como lugar de memoria, pero también como herramienta política.

Eso personalísimo que es la amistad irrumpe en la esfera social como el gesto político que trastoca las relaciones de poder, postulando el amor al otro como la única fuerza capaz de enfrentar al poder y vencerlo, despojando de poder a quienes han antepuesto sus intereses personales al bien común. Las relaciones humanas de solidaridad, amistad, compañerismo y, en fin, amor al prójimo, operan en el relato de Hernández como dispositivos de rebelión que desinstala las relaciones de poder sobre las que se instaura la democracia liberal-burguesa, como si inundar el espacio público con lo más íntimo fuera la única manera de hacer posible una verdadera transformación social.

Casi al final de Problemas en el paraíso, Slavoj Žižek reflexiona sobre este asunto para mostrarnos la fuerza y el papel fundamental del amor revolucionario. Para ello toma, de aquí y de allá, algunas frases del Ché Guevara: «Déjeme decirle, a riesgo de parecer ridículo, que el verdadero revolucionario está guiado por grandes sentimientos de amor. Es imposible pensar en un revolucionario auténtico sin esta cualidad», dice el argentino. En otra, afirma: «Hay que endurecerse sin 
perder jamás la ternura». Finalmente, el Ché postula una visión mucho más descarnada de la revolución:

El odio como factor de lucha; el odio intransigente al enemigo, que impulsa más allá de las limitaciones naturales del ser humano y lo convierte en una efectiva, violenta, selectiva y fría máquina de matar. Nuestros pueblos tienen que ser así; un pueblo sin odio no puede triunfar sobre un enemigo brutal. (Žižek, Problemas 232)

Ese odio, explica Žižek, contraría al amor que debía guiar los actos de un verdadero revolucionario solo en apariencia. Parafraseando a Kant y a Robespierre, el crítico esloveno nos recuerda que «el amor sin crueldad es impotencia» y que «la crueldad sin amor es una pasión ciega y efímera» (Žižek, Problemas 232-233). Pero dando todavía un paso más allá, Žižek establece una analogía entre ese amor-odio postulado por el Ché como principio revolucionario y la fe cristiana, usando una cita del Evangelio según San Lucas, en el que éste atribuye a Cristo la sentencia de que: «Si alguno viene donde mí y no odia a su padre, a su madre, a su mujer, a sus hijos, a sus hermanos, a sus hermanas, y hasta su propia vida, no puede ser discípulo mío (14:26)» (Žižek, Problemas 233). Es ese amor-odio radical, el gesto infinitamente desgarrador que de él puede desprenderse, la fuerza que puede destruir el orden establecido y mostrar, al menos por un instante, la Libertad:

La autentica liberación revolucionaria se identifica de manera mucho más directa con la violencia: es la violencia como tal (el gesto violento de deshacerse de algo, de establecer una diferencia, de trazar una línea de separación) lo que libera. La libertad no es un bienaventurado estado neutral de armonía y equilibrio, sino el mismísimo acto violento que perturba ese equilibrio. (Žižek, Problemas 233-234) 
El amor-odio implacable y liberador es lo que vemos operar en la rebelión del Caracazo. La amistad entre los co-protagonistas de Lo que va dictando el fuego se restituye en el espacio de lo social y de lo político para hacer posible la comunión y el encuentro con el Otro, general, colectivo, es decir, con los otros todos, para hacer posible la rebeldía contra el orden opresor y desplazar el poder. Los comunes se identifican, se hacen idénticos: las diferencias se disuelven. Los individuos fraguan entonces una amistad en la militancia política y esos vínculos políticoafectivos hacen posible un sujeto colectivo, en rebeldía. Por eso aquí la amistad es central en la escritura de esa memoria, en el relato de esa rebelión; por eso la historia de la amistad y de la rebelión se cuentan juntas. El narrador construye el relato de la batalla para-y-con ese amigo ausente: el pasado gira en torno a él, sobre él, a su alrededor. Jaurena ha muerto, lo han matado, pero la narración lo restaura en la memoria y ese producto fantasmático del deseo es no solo necesario sino imprescindible a la narración del pasado común, porque la narración de esa memoria se estructura alrededor de esa amistad. La memoria privada trasciende a hecho social, a bien común, colectivo: «Teníamos veinte años y queríamos, a toda costa, encontrarnos con otra historia. Esa que para los poderosos sólo podía ser una historia de lo imposible» (Hernández 33).

La juventud aquí es sinónimo de rebelión, de resistencia, de revolución. Una pared que se levanta, junto al pueblo, contra la opresión. Esa lucha conlleva toda una carga moral, pero también toda la tragedia que puede acarrear. La muerte de Jaurena, su asesinato, lo constata. Pero esa misma muerte, ese crimen, no desmerece la lucha, no opaca la batalla política. Tampoco el uso de la fuerza. Al contrario, la memoria estructura la épica de la revuelta popular como Acontecimiento (Badieu / Žižek), es decir, como acción transformadora. Narrador y narratario coprotagonizan la memoria de una revuelta que los supera, que está más allá de ellos, pues involucra un sujeto colectivo nacional, el país todo. El carácter épico de la refriega, justifica la violencia, porque esta se ejecuta desde una colectividad en lucha contra el sistema que la oprime. La violencia del Caracazo en la escritura de Hernández es la violencia fundadora de la libertad y por eso se identifica con esa violencia 
revolucionaria benjamineana que rescata y replantea Žižek. Ya lo advertía antes Hanna Arendt, «bajo ciertas circunstancias, la violencia —actuando sin argumentación ni palabras y sin consideración de las consecuencias - es el único medio de restablecer el equilibrio de la balanza de la justicia» (86). La violencia del Caracazo respondió a un reclamo colectivo de justicia e iba dirigida contra un Estado que había perdido ya entonces toda legitimidad.

En la memoria de esa revuelta, en la refriega con y por los otros, ambos, narrador y narratario fastasmático logran fundirse con la turba y desaparecer. Con los otros, se construye el nosotros social que legitima la lucha. La turba, el tumulto, la masa social, se hace sujeto, cobra protagonismo, es una conjunción de deseos y voluntades que conforma el sujeto colectivo, comunitario, que hace frente y repele a los agentes del poder, poniendo en jaque todo el establishment. Ahí el Acontecimiento, el instante en el que es posible vislumbrar la Utopía. Al menos momentáneamente, la multitud toda conforma un único sujeto histórico capaz de trascender las circunstancias que lo oprimen. Ese sujeto está por eso mismo vinculado a su presente, es partícipe y protagonista de los eventos sociales y políticos de su tiempo:

A veces una muchedumbre cruza cierto umbral y se convierte en algo innumerable. No puede ser contada aunque una computadora establezca el número exacto de sus integrantes. Su potencia ya no es cuestión de aritmética. Tampoco su temporalidad es un asunto que resuelvan calendarios o relojes. Es como si esa muchedumbre fuese atravesada por fuerzas innombrables. Por miles de otras muchedumbres fantasmales o virtuales que se suman a la potencia de todos los cuerpos concretos que se encuentran tomando las calles. Puedes llamar a ese tipo de multitudes como quieras, ponerles nombres genéricos como: "sujeto de la historia", “actualización de la memoria colectiva", "deseo social”, "máquinas de guerra", etc. El nombre que quieras. Pero lo que importa es otra cosa, al menos en lo que se refiere a la muchedumbre que irrumpió durante el 
CATEDRAL TOMADA: Revista de crítica literaria latinoamericana / Journal of Latin American Literary Criticism La memoria entre cenizas: un diálogo im-pertinente entre Tiempos del incendio de José Roberto Duque y Lo que va dictando el fuego de Juan Antonio Hernández.

Caracazo: el encuentro milagroso entre lo que fue y lo que puede ser en un punto donde se produce la afirmación más radical de la igualdad. (Hernández 77)

Ese «encuentro milagroso entre lo que fue y lo que puede ser» es lo que define Žižek como «Acontecimiento», que describe como un estallido social y político tras el que «brilla una dimensión utópica, la dimensión de la emancipación universal» (Žižek, Violencia 59-60). Se trata de una operación de «apertura verdaderamente utópica» determinada por la «unidad entusiasta» de «los "oprimidos", "la parte de ninguna parte", aquellos sin un lugar definido en la sociedad» (Žižek, Violencia 122) durante el que se suspende toda diferenciación impuesta como sistema. Es ahí, en ese instante, donde el Jaurena de Juan Antonio Hernández cobra cuerpo y revive, se hace de verdad, memoria, no ya en la imaginación y el deseo del narrador, sino en el espíritu de rebeldía que sobrevive al Caracazo.

La fuerza de la ficción eleva los eventos del Caracazo a nivel del «Acontecimiento» y solo así es posible vencer el infranqueable límite de la muerte, para hablar otra vez con el amigo ausente. Esa trascendencia, dota de sentido incluso a la muerte. No se trata de que El Caracazo marque el fin de un período histórico-social, de un modelo de Nación fundado en la exclusión y la represión; tampoco de que haya sido una de las primeras manifestaciones anti-neoliberales del continente. Lo que trasciende la revuelta en acontecimiento es la violencia que inunda todo resquicio de la vida ciudadana, desatascando el entramado sociopolítico mismo. La explosión suspende el statu quo, resquebraja la red de relaciones de poder, quiebra el establishment, lo que hace posible vislumbrar — por un instante al menos - un porvenir distinto, una sociedad radicalmente igualitaria:

lo que cuenta no es la transformación de las relaciones de poder y dominio entre los agentes sociopolíticos reales, la redistribución del control social, etcétera, sino el propio hecho de trascender —o, más bien, de cancelar 
momentáneamente- este propio dominio, la aparición de un ámbito diferente de "voluntad colectiva" como puro sentido-acontecimiento, en el que todas las diferencias se borran, se vuelven irrelevantes. (Žižek, En defensa 116-117)

Aun cuando el sueño emancipador que acompaña y define al Acontecimiento sea «el exceso traicionado por la realidad del mercado que se impone 'el día siguiente'», debemos tener presente que ese exceso no es superado, descartado o abolido, sino «traspuesto al estado virtual, para seguir acechando el imaginario emancipatorio como sueño que espera para ser realizado» (Žižek, Violencia 59-60). No se trata sin embargo de un momento glorioso, todo lo contrario. La sublevación conlleva violencia y sangre y muerte. El levantamiento de los oprimidos recurre a la violencia revolucionaria como única vía posible de acabar con la violencia del poder, pero convoca también la represión y la muerte que emana desde el aparato mismo de poder:

Así fue como, de golpe, nos encontramos, con aquellas dos pistolas, del lado de toda esa masa humana, una multitud que pareció quedar congelada, totalmente inerme, en el vórtice de un vendaval de plomo que la Guardia Nacional y uno que otro DISIP comenzaron a descargar con calculada brutalidad. Curiosamente no recuerdo sonido alguno. No recuerdo gritos o ráfagas de disparos. Es como si el demonio de la memoria, sobrepasado por todo aquello, se hubiese concentrado, sin consultármelo, en registrar secuencias de imágenes, colores y gestos. Es por ello que jamás olvidaré el rostro desencajado de una mujer embarazada que cayó muy cerca de nosotros con un tiro en el vientre. El cuerpo, casi partido en dos, de un niño que llevaba algo de comida enlatada y que se regó sobre el asfalto. Tu propio rostro Jaurena (luego me di cuenta que pasaba lo mismo con el mío) cubierto de sangre por las esquirlas de las balas de fusil que llovían sobre un parapeto que encontramos, un pequeño muro, demasiado 
pequeño, en la esquina de una de esas aceras propias de la arquitectura irregular de los barrios. Muy pronto nos quedamos sin balas. Accionar nuestras armas en aquel trance no había sido solamente suicida sino totalmente inútil. Entonces te escuché maldecir el instante en que decidimos dejar la subametralladora guardada. Fue allí, cuando la Guardia comenzó a avanzar, siempre disparando, como intentando una maniobra de pinza, envolvente, contra la gente que corría hacia la parte alta del barrio, fue ese el momento en que decidiste tirar una de las dos granadas contra la vanguardia de los militares. Automáticamente nos lanzamos contra el suelo, apoyándonos sobre los antebrazos, esperando un estallido que no se produjo. Y ahora es como si se hubiese abierto, en una milésima de segundo, una brecha en el vasto silencio en el que se encuentran guardadas todas esas imágenes en mi cabeza, para permitirme escuchar la granada rebotando, sordamente, contra el pavimento, rodando morosamente, sin apurarse. Te asomaste. Luego me contaste que viste a los guardias retroceder despavoridos. De manera automática salimos corriendo hacia arriba, hacia el bulevar, aprovechando la confusión del enemigo. Apenas habíamos comenzado a correr cuando se reinició el vendaval de plomo. Fue una carrera desesperada, sin aliento, sin detenernos hasta que alcanzamos una barricada hecha de carros quemados y contenedores de hierro, casi llegando a la entrada de la fábrica de cementos. (Hernández 76-77)

No es de extrañar que la referencia tras esa reflexión sobre la violencia, sea Walter Benjamin. El filósofo alemán le sirve a Hernández para referenciar la necesidad de transformación que precede y sigue a los eventos del Caracazo; para reconocer en esa violencia que sacudió Caracas y varias otras ciudades venezolanas, un levantamiento legítimo contra un sistema político que, amparado en formalismos democráticos, imponía por la fuerza un régimen de exclusión y pobreza: 
[...] ahora tan sólo quisiera hablarte de una lectura que nunca compartimos. Fue algo que escribió un judío comunista que terminaría por matarse, en la frontera entre Francia y España, para no caer en manos de los nazis. Era un tipo al que le gustaba escribir sobre antiguos juguetes y símbolos de la cábala, sobre ruinas y ángeles mudos, sobre el surrealismo, Chaplin y Kafka. Era un judío errante, literalmente, vagando por toda Europa, buscando, en medio de toda la destrucción fascista, el futuro que habita en el pasado. (Hernández 36. Énfasis nuestro)

El sueño de emancipación no se cumplió. Las fuerzas del orden impusieron la normalización a sangre y fuego. La represión se impuso de nuevo como lo había hecho a lo largo de todo el período puntofijista — desde la represión de la huelga obrera del 58 y los levantamientos militares del 61-62, atravesando las masacres de Cantaura, Yumare y El Amparo, hasta los sangrientos episodios del Caracazo. El relato de Hernández no deja de concatenar esos hechos, porque la amenaza de la violencia se balancea siempre sobre cualquier atisbo de insurrección o emancipación. La sucesión de estos eventos ilustra la violencia y la represión como una política de Estado sostenida a lo largo de todo el periodo puntofijista: «Esa verdad radical tenía mucho que ver con la atmósfera de alucinación que adquiría, por momentos, la violencia que siempre nos amenazaba. Su carácter de pesadilla diseñada para preservar el orden» (Hernández 52). Pero a esa represión se opuso siempre la rebelión: balo la aparente calma, la revolución late como posibilidad, como potencial horizonte, como porvenir. En esa latencia, la muerte de Jaurena también cobra sentido, como memoria, como relato de la lucha, como desobediencia. Después de todo, afirma Hernández al final del relato, «la memoria profética de los rebeldes que vendrán es un refugio preferible a las falsas promesas de la resurrección o del Paraíso» (Hernández 94). 
CATEDRAL TOMADA: Revista de crítica literaria latinoamericana / Journal of Latin American Literary Criticism La memoria entre cenizas: un diálogo im-pertinente entre Tiempos del incendio de José Roberto Duque y Lo que va dictando el fuego de Juan Antonio Hernández.

\section{Bibliografía}

\section{Corpus}

Duque, José Roberto. Tiempos del incendio. Caracas: El perro y la rana, 2014.

Hernández, Juan Antonio. Lo que va dictando el fuego. Caracas, Trinchera, 2015.

\section{Consulta}

Arendt, Hannah. Sobre la violencia. Madrid: Alianza Editorial, 2012.

Battaglini Oscar. Ascenso y caída del puntofijismo (1958-1998). Caracas, Galac, 2011.

. La posguerra fría y la política de seguridad y defensa del Estado venezolano. Caracas: FACES / UCV, 2002.

Benjamin, Walter. Conceptos de filosofía de la historia. Argentina: Terramar, 2007.

Derrida, Jaques. Memorias para Paul de Man. España: Gedisa, 1998.

Deleuze, Gilles y Félix Guattari. Rizoma (Introducción). 1976. España: Pre-textos, 2005.

Foucault, Michel. La verdad y las formas jurídicas. España: Gedisa, 2005.

Halbwachs, Maurice. La memoria colectiva. Buenos Aires: Miño y Dávila editores, 2011.

Izard, Miguel. El poder, la mentira, la muerte. De El Amparo al Caracazo.

Caracas: Ministerio del Poder Popular para la Cultura, 2012.

Iturriza López, Reinaldo. 27 de febrero: interpretaciones y estrategias. Caracas: Ministerio del Poder Popular para la Cultura, 2012.

Jelin, Elizabeth. Los trabajos de la memoria. Madrid: Siglo XXI editores, 2002.

Piglia, Ricardo. Antología personal. España: Anagrama, 2015.

Pons, María Cristina. Memorias del olvido. La novela histórica de fines del siglo XX. México: Siglo XXI, 1996.

Rada Aragol, Yasmín y Orlando José Contreras. Protesta estudiantil y represión en Venezuela 1983-1993. Venezuela: Ministerio del Poder Popular para la Cultura, Archivo General de la Nación, Centro Nacional de Historia, 2010.

Ricoeur, Paul. La memoria, la historia, el olvido. Buenos Aires: Fondo de Cultura Económica, 2008.

Sarlo, Beatriz. Tiempo pasado. Cultura de la memoria y giro subjetivo. Una discusión. México: Siglo XXI Editores, 2006.

Todorov, Tzvetan. Los abusos de la memoria. España: Editorial Paidós, 2008.

Žižek, Slavoj. Problemas en el paraíso. Del fin de la historia al fin del capitalismo. Barcelona: Anagrama, 2016.

. En defensa de causas perdidas. Madrid: Ediciones Akal, 2011.

. Violencia en acto. Conferencias en Buenos Aires. Analía Hounie (Comp.). Buenos Aires, Paidós, 2004.

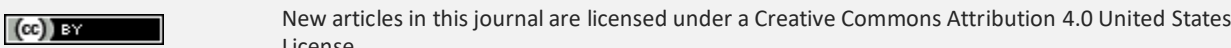

ULS D-Serle This site is published by the University Library System, University of Pittsburgh as part of its D-Scribe Digital Publishing Program and is cosponsored by the University of Pittsburgh Press.
} 